editors:

Tali K. Walters

J. Martin Ramirez

Małgorzata Kossowska

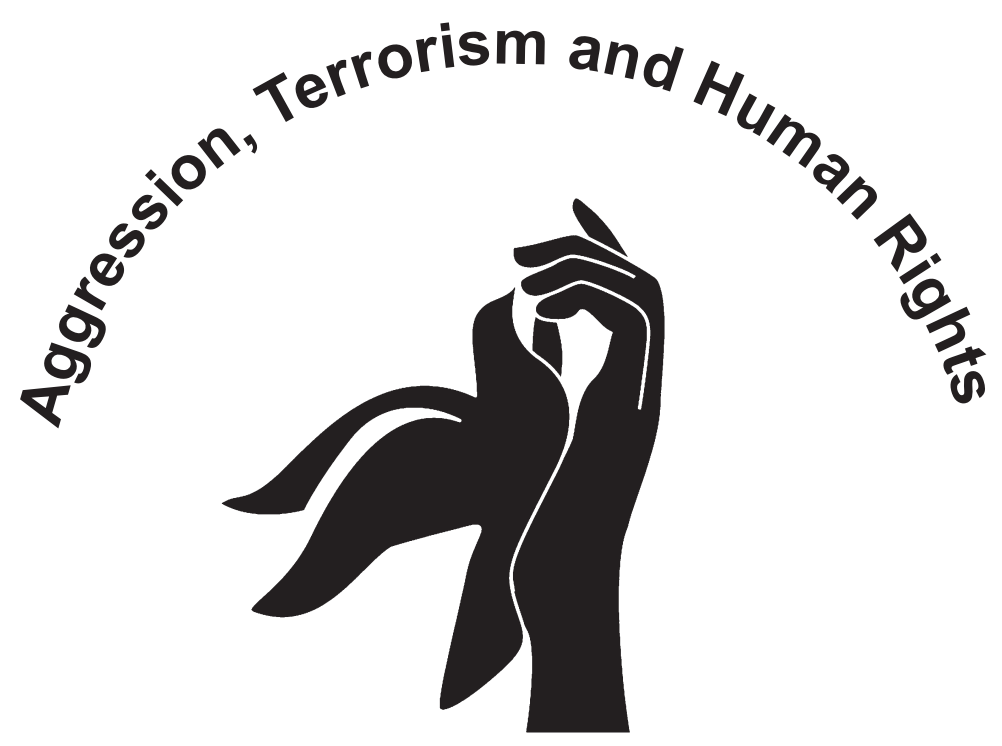




\section{C.I.C.A. SERIES OF BOOKS}

1. Aggression: Functions and Causes (1985)

J. Martin Ramirez \& Paul F. Brain (eds.)

2. Cross-disciplinary Studies on Aggression (1986)

Paul F. Brain \& J. Martin Ramirez (eds.)

3. Essays on Violence (1987)

J. Martin Ramirez, Robert A. Hinde \& Jo Groebel (eds.)

4. Research on Aggression (1987)

J. Martin Ramirez (ed.)

5. \& 6. International Journal of Neuroscience, $1988 \mathrm{Vol} 41$

$(3 \& 4)$

J. Martin Ramirez \& David Benton (eds.)

7. Terrorism: Psychological Perspectives (1989)

Jo Groebel \& Jeffrey Goldstein (eds.)

8. Terrorismo (1989)

Francisco Gómez-Antón \& Carlos Soria (eds.)

9. $\quad$ Aggression in Children (1989)

Lea Pulkkinen \& J. Martin Ramirez (eds.)

10. Comparative Psychobiology of Aggression (1990)

Orlaldo Gutierrez (ed.)

11. Violence. Some Alternatives (1994)

J. Martin Ramirez (ed.)

12. Neuropsiquiatría de la Conducta Agresiva (1995)

J. Martin Ramirez \& Hector Peñaloza (eds.)

13. Cross-cultural Approaches to Aggression and Reconciliation (2001)

J. Martin Ramirez \& Deborah Richardson (eds.)

14. Neuroscience and Biobehavioural Reviews (2006)

J. Martin Ramirez (ed.)

15. Aggression and Terrorism (in press)

J. Martin Ramirez (ed.)

16. Interdisciplinary Analyses of Terrorism (in press)

Daniel Antonius, Adam D. Brown, Tali K. Walters, J.

Martin Ramirez, Samuel Justin Sinclair (Eds.) 


\section{SOCIETY FOR TERRORISM RESEARCH PUBLICATIONS}

1. Interdisciplinary Analyses of Terrorism (in press)

Cambridge Scholars Publishing

Daniel Antonius, Adam D. Brown, Tali K. Walters, J. Martin Ramirez, Samuel Justin Sinclair (eds.)

2. Terrorism Research (first edition scheduled for publication Fall 2008)

The Journal of the International Society for Terrorism Research

Samuel Justin Sinclair \& Daniel Antonius (eds.)

\section{POLISH ASSOCIATION OF SOCIAL PSYCHOLOGY PUBLICATIONS}

1. Different aspects of altruism (2008)

Wydawnictwo Naukowe Scholar

Dorota Rutkowska \& Anna Szuster-Kowalewicz (eds.)

2. Social paths of cognition (2005)

Gdańskie Wydawnictwo Psychologiczne

Małgorzata Kossowska, Magdalena Śmieja, \& Sławomir Śpiewak (eds.)

3. Issuing peer-reviewed quarterly Psychologia Społeczna (Social Psychology) since 2006 



\title{
2008 CICA-STR
}

\author{
International \\ Conference
}

on

\section{Aggression, Terrorism and \\ Human Rights}

Program and Abstracts

Zakopane, Poland

15th - 18th July 2008 



\section{CONTENT}

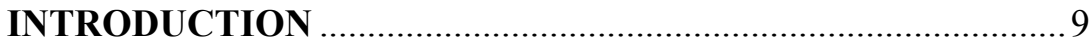

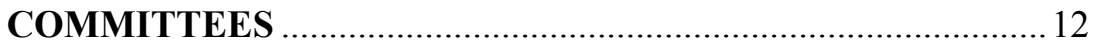

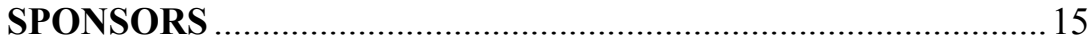

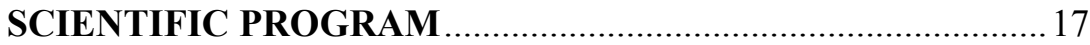

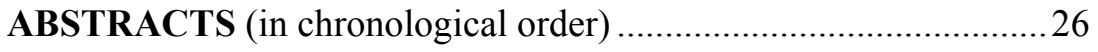

LIST OF PARTICIPANTS (in alphabetical order) ………..............57

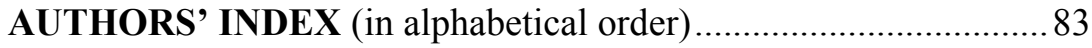

NOTES 



\section{INTRODUCTION}

Terrorism is the very antithesis of human rights. (Human Rights Watch)

The Coloquios Internationales sobre Cerebro y Agresión (CICA) and the Society for Terrorism Research (STR) welcome you to their second annual, co-sponsored, international conference on aggression and terrorism. In the world fight against terrorism, each country has an international human rights obligation that cannot get lost in the counterterrorism efforts. In this year's conference, we celebrate the $60^{\text {th }}$ year of the Universal Declaration of Human Rights through a Keynote Speech, scientific presentations, and a special Round Table to share personal experiences.

We believe that when research on aggression and terrorism is informed by the integration of theories and findings from multiple disciplines, more effective policies worldwide will emerge. Not only will effective policies emerge, but frameworks for implementation will more likely avoid violations of human rights if this approach is taken.

Our responsibility is to provide opportunities to our interdisciplinary colleagues to learn, share, and influence each other.

- Learn - Researchers from around the world will present their findings and offer directions for future study.

- Share - Through structured discussion, play, and casual conversation, share your questions, answers, and ideas with colleagues.

- Influence - Your research will contribute to worldwide policy as each country grapples with managing its response to terrorism and other aggressions.

In this way, we can contribute to the diminishment of aggression and terrorism in the world, and support human rights amongst all. 
This year, close to 65 scientists from 24 countries of all five continents are gathered to exchange their thoughts and ideas on aggression and terrorism. They come from Europe (Belgium, Bulgaria, Croatia, England, Hungary, Poland, Portugal, Slovenia, Spain, Sweden, The Netherlands, and Wales), Asia (Iran, Iraq, Palestinian Territory, and United Arab Emirates) Africa (Nigeria, Ghana, Gambia, and South Africa), North America (Canada and USA) and Oceania (Australia). You will have the opportunity to participate in four keynote speeches, six sessions of scientific presentations, and a Poster Session. New this year will be a time set aside for an informal Round Table discussion of personal experiences of aggression, terrorism, and human rights violations.

We are pleased to welcome our keynote speakers from Poland and the USA. Arthur J. Kendall, President of Capital Area Social Psychological Association (Washington, DC) and STR Advisory Board member, will commemorate the Declaration of Human Rights in his speech Celebrating the 60th Anniversary of the Universal Declaration of Human Rights. Yonah Alexander, Director of the Inter-University Center for Terrorism Studies, will consider the question Superterrorism in the 21st Century: Will Civilization Survive? Adam Frączek, Former President of the International Society for Research on Aggression will inform us about Terrorism and Interpersonal Aggression: Conceptual Considerations from Social, Developmental Perspectives. And Gary LaFree, prominent criminologist and Director of the National Center for the Study of Terrorism and Responses to Terrorism (START), will share his ideas on Countering Myths about Terrorism.

We received a broad, robust response to the Call for Papers for this Conference. Researchers and thinkers will present their ideas on the following topics: Aggression and Violence; International Security; Legal Approaches to Terrorism; Psychological Approaches to Terrorism, with a special focus on the impact on human rights and the image of the terrorist; and Psychological Determinants and Consequences of Terrorism Threat. 
Zakopane, a most beautiful town an hour south of Kraków, on the border to Slovakia, is our location host for this year's conference. Its district is considered the most attractive tourist region in Poland, with beauty to be found in the Tatra Mountains, the hills of Podhale, as well as in the town itself. Zakopane is known for its outstanding winter skiing and summer alpine hiking. Please take advantage of these gifts!

We invite all participants, presenters, and esteemed guests to take the opportunity of the $2008 \mathrm{CICA} / \mathrm{STR}$ Conference on Aggression, Terrorism, and Human Rights to learn from each other, share your thoughts and ideas, and, ultimately, influence the steps our governments take to reduce the incidents and threats of terrorism in the world.

\section{Learn * Share* Influence}

J. Martin Ramirez, Tali K. Walters, and Malgorzata Kossowska

Zakopane, Poland

15 - 18 July 2008 


\title{
CONFERENCE CHAIRS
}

\section{SCIENTIFIC COMMITTEE}

\author{
J. Martín Ramírez \\ CICA Chairman \\ and \\ President of the Spanish Pugwash Movement \\ (Madrid, Spain)
}

\begin{abstract}
Tali K.Walters
Board Vice-President and Director of Conference Planning Society for Terrorism Research

(Boston, USA)
\end{abstract}

\section{ORGANIZING COMMITTEE}

\author{
Malgorzata Kossowska \\ President of Polish Association of Social Psychology \\ (Kraków, Poland)
}




\section{SCIENTIFIC COMMITTEE}

John Archer, Former President of the International Society for Research on Aggression (ISRA), University of Central Lancashire (United Kingdom)

Caroline Blanchard, President of ISRA University of Hawaii (USA)

Adam Frączek, Past President of ISRA Maria Grzegorzewska Academy of Special Education (Poland)

Arthur J. Kendall, President of the Capital Area Social Psychological Association, Advisory Board of the Society for Terrorism Research (STR) (USA)

Malgorzata Kossowska, President of the Polish Association of Social Psychology, Jagiellonian University (Poland)

Alice Katherine LoCicero, Past President of STR Endicott College (USA)

Deborah S. Richardson, Past President of ISRA, Co-Organizer of the Augusta CICA University of Georgia (USA)

J. Martín Ramírez, Chairman of CICA, President of the Spanish Pugwash Movement, Universidad Complutense de Madrid (Spain)

Samuel Justin Sinclair, President of STR Massachusetts General Hospital/Harvard Medical School (USA)

Tali K. Walters, Board Vice-President and Director of Conference Planning of STR

Tuft University Medical School/Tufts Medical Center (USA)

Guillermo Velarde, President of the Institute of Nuclear Fusion Universidad Politécnica de Madrid (Spain) 


\section{ORGANIZING COMMITTEE}

Michal Chmiel, Institute of Psychology, Jagiellonian University (Poland)

Katarzyna Jaśko, Institute of Psychology, Jagiellonian University (Poland)

Małgorzata Kossowska, Polish Association of Social Psychology (Poland)

Tomasz Kubik, Institute of Psychology, Jagiellonian University (Poland)

Kendall McKay, Case Western University, Society for Terrorism Research (USA) 


\section{SPONSORS}

\section{Scientific Sponsors}

CICA The Coloquios Internacionales sobre Cerebro y Agresión has promoted and supported a multidisciplinary understanding of conflict and aggression through international, residential colloquia on the relationship between the brain and the social context of aggression. Since 1983, with the first CICA in Seville, 25 scientific meetings have being held in several countries of Europe, Asia, America and Africa.

STR The Society for Terrorism Research was launched in mid2006 as an international, multi-disciplinary organization of theoretical and empirical researchers in the behavioral sciences. STR's mission is to enhance knowledge and understanding of terrorism through the integration of findings from the fields of anthropology, biology, economics, political science, psychology, sociology, law and other behavioral sciences.

PSPS The Polish Association of Social Psychology's aims are to promote research in the field of social psychology in Poland. It sets up a variety of activities (general conventions, small group meetings, schools for young scientists) and it creates publication outlets for significant research contributions (issuing peer-reviewed quarterly Psychologia Społeczna and Monographs in Social Psychology). As such, it contributes to the scientific communication among Polish social psychologists.

\section{Institute of Psychology at the Jagiellonian} University - One of the top Polish institutes of research psychology, at Poland's oldest university 
CRP - The Center for Research on Prejudice is a special unit of Faculty of Psychology, University of Warsaw, devoted to interdisciplinary studies on xenophobia, racism, anti-semitism and prejudice in general. It specializes in basic and applied research in social psychology of stereotyping and prejudice.

\section{Financial Sponsors}

- Institute of Psychology at the Jagiellonian University

- The Polish Association of Social Psychology

\section{Social Sponsors}

- PWN - Polish Scientific Publishers are the major and most renowned Central European publisher of scientific, educational and professional titles, such as dictionaries, encyclopaedias, textbooks and publications in science and the humanities. Based in Warsaw and founded in 1951, PWN has maintained its intense presence in the non-fiction market and for over half a century retained the status of a major scientific publishing house, comparable to Oxford, Cambridge or John Wiley \& Sons, with whom PWN cooperates on a daily basis. It has just published the book by John Horgan "The Psychology of Terrorism" with introduction of Adam Frączek, and above ten other books about aggression and conflict.

- Tygodnik Podhalański - daily local newspaper

- Council of Zakopane 


\section{SCIENTIFIC PROGRAM}

\section{TUESDAY}

Afternoon Arrival of participants and registration 20’00 Dinner

$21^{\prime} 00 \quad$ Informal gatherings

\section{WEDNESDAY}

8'00-9'00 Breakfast \& Registration

\section{9'00-10'00 Opening Ceremony}

Małgorzata Kossowska, Chair of the Organizing Committee

J. Martin Ramirez, Co-chair of the Scientific Committee Janusz Majcher, Councelor of local government Tali K. Walters, Co-chair of the Scientific Committee 


\section{0'30-13'00 Session A: A Psychological Approach to Terrorism}

Chair: Tali K. Walters (USA) Society for Terrorism Research

Participants:

Blanka Rip, Shira Fishman, Arie W. Kruglanski, \& Edward Orehek (USA/Canada)

The Psychology of Terrorism: A Review of Literature Since 9/11

Tomasz Edward Kubik \& Malgorzata Kossowska (Poland)

Various Perspectives on Terrorist Images

Alice LoCicero (USA)

Raising Martyrs: The Rest of the Story

Javier Martin-Peña, Alvaro Rodríguez-Carballeira, Jordi Escartín, Clara Porrúa, \& Federico Javaloy (Spain)

A psychosocial analysis of the psychological violence strategies and the consequences perpetrated by the ETA terrorist network in the Basque Country.

Kinga Williams (Hungary/United Kingdom) \& Abdolhossein Abdollahi (Iran)

"Vicious Cycles of War and Conflict"- Terror Management Theory and Practice

Part 1 - Kinga Williams

Terror or Tolerance?

Part 2 - Abdolhossein Abdollahi

Intergroup conflicts and the routes through which we may control them: A terror management perspective 


\section{3'00-14'00 Lunch}

\section{4'30-15'30 Keynote Address}

Chair: $\quad$ Malgorzata Kossowska (Poland)

Speaker: $\quad$ Arthur J. Kendall (USA)

Celebrating the 60th Anniversary of the Universal Declaration of Human Rights

\section{5'30-16'00 Break}

\section{6'30-19'00 Session B: A Legal Approach to Terrorism}

Chair: Arthur J. Kendall (USA)

Participants:

Amanda M. Sharp Parker (USA)

Predicting Fatalities in Domestic Terror Events: Do Human Rights Violations Matter?

Anita Blagojevic (Croatia)

About balance between the fight against terrorism and the protection of fundamental human rights in the context of the European System

Sam Mullins (Australia)

Parallels between Crime \& Terrorism: A Social Psychological Perspective 
Angela Scholes \& Margaret Wilson (United Kingdom)

Defining political assassinations: How are they different to other types of terrorist incidents?

Steven John Thompson (USA)

Shut Up or Die: The Jyllands-Posten Cartoons, Media Behaviorism and Systemic Defiance

Vivian Salama (United Arab Emirates)

From Training Camps to Virtual Sanctuary: The Impact of Islamic Jihad in the Virtual World

\section{0'00 Dinner TATRA EVENING WITH FOOD AND MUSIC!}

\section{THURSDAY}

8'00-9'00 Breakfast

9'00-10'00 Keynote Address

Chair: $\quad$ Guillermo Velarde (Spain)

Speaker: $\quad$ Yonah Alexander (USA)

Super-terrorism in the 21st Century: Will Civilization Survive? 


\section{0'00-11'00 Break and Poster Session}

Iciar Galicia \& J. Martin Ramirez (Spain)

Influence of Body Weight Loss on Aggressiveness

Jose M. Andreu, Carolina Marín, M. Elena Peña, Rocio Mateos \& J. Martin Ramirez (Spain)

Relationship between expressive attribution style and Reactive-Proactive Aggression

Marek Smulczyk (Poland)

Measurement of Psychological Mechanisms of Aggressive Behavior (Assumptions and Instrument)

Faris K. O. Nadhmi (Iraq/Sweden)

Death Anxiety Perceived by University Academics in Iraq

Marcin Kazimierz Grega (Poland)

Right-wing terrorism in the United States with reference to Oklahoma City bombing on 19th April 1995 (Timothy McVeigh psychological and sociological case study)

Małgorzata Kossowska \& Mariusz Trejtowicz (Poland), Alain Van Hiel (Belgium), Soledad de Lemus (Spain), \& Robin Goodwin (United Kingdom)

Authoritarian orientations, threat of terrorism and preference for counter-terrorism strategies: Cross-culture comparisons

\section{1'00-13'00 Session C: International Security}

Chair: Yonah Alexander (USA)

Participants:

Peter Tikuisis (Canada)

Weak States and Terrorism 
Adam Dolnik (Australia)

Negotiating Hostage Crises with the New Terrorists

Tolya Angelova Stoitsova (Bulgaria)

Societal Reactions to Terrorism in Bulgaria: Mass Media and Security Institutions Interaction

Guillermo Velarde \& Natividad Carpintero Santamaria (Spain)

Counterterrorism: An Analysis of The Non-Conventional Threat

Albert Jongman (The Netherlands)

Trends in Suicide Terrorism

\section{3'00-14'00 Lunch}

\section{4'30-15'30 Keynote Address:}

Chair:

J. Martin Ramirez (Spain)

Speaker:

Adam Frączek (Poland)

Terrorism and Interpersonal Aggression: Conceptual

Considerations from Social, Developmental

Perspectives

\section{5'30-16'00 Break}




\section{6'00-18'30 Session D: Aggression and Violence}

Chair:

Adam Frączek (Poland)

Participants:

J. Martin Ramirez \& Jose M. Andreu (Spain)

Usefulness of Categorizing Functional Aggression

Jose M. Andreu, Carolina Marín, Rocio Mateos, \& J. Martin Ramirez (Spain)

Cognitive Justification of Reactive-Proactive Aggression among Adolescents

Lucyna A. Kirwil (Poland)

Normative beliefs about aggression, emotional responding to violence and proactive/reactive aggression in young adults

Faris K. O. Nadhmi (Iraq/Sweden)

Sexual Violence against the Iraqi Women: Anthropopsychological Perspective

Tina Lindhard (South Africa/Spain)

The Mutilation of "Womeness" and the Right to Be Human

\section{8'30 Round Table: Experiences with Aggression, Terrorism, and Human Rights Issues}

Chair: $\quad$ Lucyna Kirwill (Poland)

Participants:

Mamdouh Darwish Jabr (Palestinian Territory)

Diamond Mark Eferigho Iriri (Nigeria)

Joseph Okpalaugo (The Gambia)

Kelvin Mensah (Ghana) 


\title{
FRIDAY
}

8'00-9'00 Breakfast

\section{9'00-10'00 Keynote Address}

Chair:

Alice LoCicero (USA)

Speaker:

\author{
Gary LaFree (USA)
}

Countering Myths about Terrorism

10'00-10'30 Break 


\section{0'30-12'30 Session E: Psychological Determinants and Consequences of Terrorism Threat}

Chair: $\quad$ Gary LaFree (USA)

Participants:

Maciej Sekerdej (Portugal) \& Malgorzata Kossowska (Poland)

Nationalism, Essentialism and Perception of Terrorist Threat

Matgorzata Kossowska \& Anna Czerniak (Poland) \& Agnieszka Golec de Zavala (United Kingdom)

Tthreat of Terrorism and Support for Antiterrorism Policies

Anja Zimmermann (United Kingdom), Bertjan Doosje \& Sven Zebel (The Netherlands), Tendayi Viki \& Dominic Abrams (United Kingdom)

Dehumanization and moral responsibility as predictors of outgroup-focused outcomes and support for terror threat prevention

Shahzad Shafqat (United Kingdom)

Extremism + Threat $=$ Terrorism: Understanding terrorism from a psycho-social perspective

\section{2’30-13'00 Closing Ceremony}

Tali K. Walters, Co-chair of the Scientific Committee \& Vice-President, STR

J. Martin Ramirez, Co-chair of the Scientific Committee and Chair, CICA

Janusz Majcher, Counselor of local government

Małgorzata Kossowska, Chair of the Organizing Committee

\section{3'00-14'00 Lunch}




\title{
ABSTRACTS
}

(in chronological order)

\section{Session A: A PSYCHOLOGICAL APPROACH TO TERRORISM}

\author{
The Psychology of Terrorism: A Review of Literature Since 9/11 \\ Blanka Rip, Shira Fishman, Arie W. Kruglanski, \& Edward Orehek \\ (USA) \\ University of Maryland
}

The September 11th terrorist attacks spurred a large body of research on the psychology of terrorism. We attempt to integrate this work into a comprehensive account of the terrorist dynamic. On the one hand, we consider the terrorist activists within their social context. That is, we review research pertaining to the psychological factors that motivate this form of extreme behavior, as well as the ideological, organizational, and social bedrocks that sustain it. On the other hand, we consider the psychological reactions evoked by acts of terror, also within their social context. This literature reveals a dual dynamicone of collective inward-turning and subsequent lashing out. Throughout this paper, we attempt to highlight the interactions and similarities between the psychological processes that lead to the emergence of terrorist activists and those that lead to (counterproductive) reactions to terrorism that fuel continued intergroup violence. Implications for long-term counterterrorism efforts are also discussed. 


\section{Various Perspectives on Terrorist Images}

Tomasz Edward Kubik \& Małgorzata Kossowska (Poland)

Jagiellonian University

Research on terrorist images is summarized, taking into account international perspectives from various countries. Special attention is paid to other variables that correlate with observed phenomena. Historical facts enable us to speculate about political and cultural reasons behind images reflected in people's opinions. In addition, various conclusions are drawn that concern potential practical implications of observed images.

Also included is an outline of promising further research in the field.

\section{Raising Martyrs: The Rest of the Story}

Alice LoCicero (USA)

Endicott College

Child terrorists inspire considerations about winning hearts and minds, because prevention and intervention are seen as possible. In order to understand the puzzling phenomenon of children who willingly and intentionally die in a terrorist attack, many citizens and researchers ask the following three questions: 1. What motivates them? 2. What motivates their parents? and 3. Why do parents celebrate their child's death? Pursuing these questions, citizens and researchers often focus on political and religious beliefs and circumstances of the community. Issues of human rights-legitimate grievances-are also cited. However, past, present, and potential future global considerations, as understood by the children and their families, are seldom included. Several of these considerations are likely to play a significant role. We consider perspectives on global bullying, unfair distribution of resources, and the global threat of nuclear disaster, as part of the background for terrorism. 


\section{A psychosocial analysis of the psychological violence strategies and the consequences perpetrated by the ETA terrorist network in the Basque Country \\ Javier Martin-Peña, Alvaro Rodríguez-Carballeira, Jordi Escartín, Clara Porrúa, \& Federico Javaloy (Spain) \\ University of Barcelona}

The harassment and the psychological violence (often named violence of persecution) perpetrated by the E.T.A. terrorist network in the Basque Country, involves serious consequences for the victims and violates the human rights, though it doesn't necessarily cause injuries and death. However, researchers have not given much attention to this issue.

To analyze this phenomenon of terrorist psychological violence, this study has two goals: 1) to delimit the psychological violence strategies perpetrated by the terrorist network by means of the construction of categories; 2) to delimit the consequences or effects that have over victims the strategies perpetrated by the mentioned network, by means of the construction of categories

It was obtained two new categorizations, from a psychosocial approach, about the psychological violence strategies and about the consequences caused by it. Both categorizations cover the contextual, emotional, cognitive and behavioural elements and show the psychological violence strategies as another way to terrify different to the terrorist attacks. 


\section{"Vicious Cycles of War and Conflict"- Terror Management Theory and Practice}

Kinga Williams (Hungary/United Kingdom)

MENSANA Intercultural Psychological Consultancy

Abdolhossein Abdollahi (Iran)

Islamic Azad University-Zarand Branch

Terror Management Theory is increasingly recognized as one of the most influential empirically proven socio-cultural constructs of our day - deserving the most comprehensive scholarly attention.

\section{$\underline{\text { Part } 1}$ - Terror or Tolerance?}

\section{Kinga Williams}

According to the Terror Management Theory, alternative cultures are a threat as they may interfere with culture's main function: to buffer against mortality awareness. The talk flags up two possibilities. One is a vicious cycle: Existential Anxiety re-created by other-culture intolerance - the other is forward-pointing, towards other-culture tolerance. Through the Mortality Management Hypothesis (e.g. Rosenblatt et al 1989), The Reverse Mortality Salience Hypothesis (Williams 2004), and the Rule Category Substitution Fallacy (Williams 2005), connections are mapped out among Mortality Awareness, Culture Distance, Culture Shock, Constitutive and Regulative Rules, Cognitive Errors, Terror Management Strategies, Culture Learning and Intercultural Dialogue. Given that the present cultural-political climate (the upsurge of fundamentalism/terrorism) is clearly the product of the vicious cycle route, mindfulness of its workings is imperative.

It is concluded that an increasingly globalized world might require a multi-cultural buffer against mortality awareness. 


\section{$\underline{\text { Part } 2}$ - Intergroup conflicts and the routes through which we may control them: A terror management perspective}

Abdolhossein Abdollahi

Terror management theory (TMT) posits that much human social behavior is driven by the need to avoid the conscious and unconscious reminders of ones death and mortality. In this talk, first I will briefly review the general findings of TMT since its inception. Then, I will point to how the activation of death reminders may instigate intergroup aggression resulting in such phenomena as war and global terrorism. Next, I will zero in on two studies conducted in Iran and the United States the findings of which indicate that when under the influence of death reminders, both Iranian and American participants tend to hold a negative attitude of Americans (for Iranians) and the US real or perceived enemies (for Americans). Finally, I will review the most recent TMT-related findings indicating that priming people with such concepts as compassion and common humanity tends to mitigate the negative intergroup effects of death reminders. 


\section{- KEYNOTE ADDRESS}

\section{Celebrating the 60th Anniversary of the Universal Declaration of} Human Rights

Arthur J. Kendall (USA)

President of the Washington Social Psychological Association

In 1946, the United Nations passed the Universal Declaration of Human Rights. It lays out the Human Rights for all people. Much of the work done in the social and behavioral sciences is directly relevant to the UDHR. At a minimum, it is relevant to Article 27, the Right to Share in Scientific Advancement. We will ask Human Rights researchers and practitioners at the meeting what help physical, social, and behavioral scientists could give them in their efforts.

The Science and Human Rights Coalition of the AAAS. Dr. Kendall will describe the coalition http://shr.aaas.org/scisocs/ and his experience with it as a representative to it from the Capitol Area Social Psychological Association. He will also suggest things social and behavioral scientists can do to help celebrate this anniversary.

The full text of the UDHR can be found at: http://www.un.org/Overview/rights.html.

A colorful poster listing the rights is available on the AAAS website: http://shr.aaas.org/www/HumanRts_Posterc.pdf.

Another new poster is expected in May. 


\section{- Session B: A LEGAL APPROACH TO TERRORISM}

\section{Predicting fatalities in domestic terror events: Do human rights violations matter}

Amanda M. Sharp Parker (USA)

University of South Florida

This paper will examine the fatality rate of domestic terrorism in 15 Western European countries between 1980-2004 ( $\mathrm{N}=5261$ events) using the TWEED dataset, originally created by Jan O. Engene. A multi level approach using MPlus will be used to examine factors related to fatality rate. At the micro level, event trend characteristics will be examined. At the macro level, characteristics of the country will be examined, including the country's level of human rights violations, as indicated by the country's average score on the Political Terror Scale (PTS); taking into account Amnesty International and the United States Department of State's human rights violation score for each country. Based on the findings, policy implications and direction for future research will be discussed.

\section{About balance between the fight against terrorism and the protection of fundamental human rights in the context of the European System \\ Anita Blagojevic (Croatia) \\ J. J. Strossmayer University of Osijek}

There is no doubt that acts of terrorism destroy human rights, democracy and the rule of law. There is also no doubt that States have legitimate reasons to take all due measures to fight against terrorism. On the other hand, in the fight against terrorism, fundamental human rights, unfortunately, come under threat. The reaction of transnational institutions to September 11, 2001 varied: while the Security Council and the EU took steps to toughen anti-terrorism efforts, the Council of 
Europe institutions in general, and the European Court of Human Rights in particular, reinforced their commitment to human rights standards. The need for a fair balance between legitimate national security concerns and the protection of fundamental rights is reflected in the International Covenant on Civil and Political Rights (which has been ratified or acceded to by 151 States), as well as in the regional European human rights treaty - in the European Convention for the Protection of Human Rights and Fundamental Freedoms. The balance in the context of the European system also articulates the "Guidelines on Human Rights and the Fight against Terrorism", adopted by the Committee of Ministers on 11 July 2002.

\section{Parallels between crime \& terrorism: A social psychological perspective}

Sam Mullins (Australia)

University of Wollongong

Although the psychology of terrorism is far from a neglected subject, there is still much to learn. 'Ordinary' criminals remain enigmatic but have proved a far more accessible population for research purposes. This paper 'bridges the gap' between the study of crime and contemporary terrorism by examining the parallels between the two, and demonstrates the utility of the former for understanding the latter. Of particular relevance are studies on the social learning and facilitation of crime, processes of social identification, group processes and the social organization of crime.

\section{Defining political assassinations: How are they different to other types of terrorist incidents? \\ Angela Scholes \& Margaret Wilson (United Kingdom) \\ University of Surrey}

Previously, research on political assassinations has focused on attempts to create profiles and typologies of assassins, based on case studies of the assassins themselves. However, there have been no 
attempts to empirically define what constitutes a political assassination. This study considers how political assassinations differ from other forms of terrorism, such as suicide bombings and hostagetaking. The range of terrorist actions available are compared in terms of their key distinguishing features. A multidimensional model is derived which allows for comparison of terrorist action with respect to a hierarchy of behaviour, ranging from that typical of terrorism in general through to the behaviours that characterize specific acts. The empirical definition of assassination, and the implications for future research are discussed.

\section{Shut up or die: The Jyllands-Posten cartoons, media behaviorism and systemic defiance}

Steven John Thompson (USA)

Clemson University

Aftermath from publication of Jyllands-Posten Muhammad cartoons in 2005 resulted in a global precedent for changes in media behavior. More than 130 people dead, death threats and murder attempts against newspaper staffs, closings of newspapers or firings of editors in more than 10 countries, and economic repercussions all quieted the media, shutting down freedom of the presses. Along with the rhetorics of fear and terror exerted over non-Muslims to not negatively address Islamic tenets in public forums, charges of self-censorship, criminality, and inciting hatred further aggressively encouraged the silence of media expression regarding critique of Islamic fundamentalist ideals. On February 13, 2008, however, several European newspapers reprinted the Bomb in the Turban cartoon in defense of free speech, and in reaction to the fatwa which called for the death of cartoonist Kurt Westengaard. This study analyzes rhetorically situational psychosocial methods and behaviors resulting from these incidents and their related events. 


\section{From Training Camps to Virtual Sanctuary: The Impact of Islamic Jihad in the Virtual World \\ Vivian Salama (United Arab Emirates/USA) \\ Journalist/Analyst}

From Hezbollah to Al-Qaeda, terrorist groups have commonly embraced the newest forms of communications technology. The Internet is no exception. Web 2.0 is by definition a place where communities of like-minded people come together to contribute and augment content and ethos respectively.

The rapidity with which this propaganda is spreading is far greater than the efforts being made to curb its threat. Many of the sites operate via secret passwords and can conceal themselves amid the 30.9 million sites accessible on the web today. Just as web surfers can access information from all over the world simply by logging on to the Internet, jihadists can now be everywhere without leaving home.

I have written one of the most extensive and detailed accounts of Jihadi activities on the web. The brilliance and sophistication of their activities was, in my mind, the most significant aspect of the study. My study provides detailed analysis of the websites studied, exposing various techniques, including web polls, web forums and more. I set up the Internet using the defining characteristics of a failed state, and structure the Muslim "ummah" as an "imagined community." 


\section{- KEYNOTE ADDRESS}

\section{Super-terrorism in the 21st Century: Will Civilization Survive?} Yonah Alexander (USA)

Director, Inter-University Center for Terrorism Studies

The post-9/11 world has brought about a new type of instability: it is more chaotic, with many areas marked by "unruliness" (e.g. Somalia) and by "rogue" states (e.g. Iran, Syria and North Korea). Religious extremism is expanding (e.g. al-Qaeda's affiliates). Ethnic, racial and national intolerance and violence are increasing. Terrorist organizations aspire to inflict maximum damage. Their links with states, coupled with optimized criminal black market activities, may open the way for the use of weapons of mass destruction and related horrors. There is a need for a reassessment of the challenges in the $21^{\text {st }}$ century and a search for better answers to the problems that are facing the world.

Among the more important issues for immediate considerations are:

1. Proliferation Trends: What is the distribution of biological, chemical and nuclear knowledge, technology and materials in the short and long terms?

2. Trends in Terrorism: What are the trends in post 9/11 conventional terrorism and the prospects for super-terrorism (actors, capabilities, motives, method of operation and targets)?

3. Impact and costs of super-terrorism: What are human, material, psychological and strategic factors?

4. Current responses to super-terrorism: What are the current responses to super-terrorism: governmental, intergovernmental and nongovernmental?

5. Requirements for the future national, regional, and global defense against super-terrorism: What are the alternative strategies to prevent and cope with super-terrorism?

In sum, will civilization survive mass destruction terrorism? The short answer is yes, if we want to. 


\title{
- POSTER SESSION
}

\author{
Influence of a Body Weight Loss on Aggressiveness \\ Iciar Galicia \&, J. Martin Ramirez (Spain) \\ Universidad Complutense Madrid
}

At a time when obesity is increasingly prevalent, many people are trying to control their body weight through dieting. Concern over the possible impacts of weight loss on violence and aggressiveness led to the present study. One hundred and fifty participants anonymously completed two questionnaires assessing their aggressiveness, age, sex, diet, recent changes in body weight, and reasons for the body weight changes. In comparison to controls, an increased level of aggressiveness was reported by participants who had deliberately lost weight but not by those who had lost weight involuntarily (passive weight-losers). The increase was stronger for hostile aggression than for instrumental aggression and is likely due to the discomfort associated with opposing one's body weight set-point.

\section{Relationship between Expressive Attribution Style and Reactive- Proactive Aggression \\ Jose M. Andreu, Carolina Marín, M. Elena Peña, Rocio Mateos \& J. Martin Ramirez (Spain) \\ Universidad Complutense Madrid}

The concept of attributional style has had considerable heuristic value in the area of aggression, where numerous studies have found that a hostile attributional style is correlated with aggression. To evaluate this hypothesis, we administered a questionnaire for characterizing aggression (the "Reactive-Proactive Questionnaire"), along with standard measures of personality (EPQ-J), and expressive attribution styles (EXPAGG), to ninety-seven adolescents. Expressive attribution style was negatively associated with both reactive and proactive aggression $(\mathrm{r}=-0.36 / \mathrm{r}=-0.40 ; \mathrm{p}<0.05)$. As in adult and child literature, characterization of aggression into two subtypes appears to be relevant 
to understanding the role of expressive representation of aggression in the complex causation of aggressive behavior.

\section{Measurement of Psychological Mechanisms of Aggressive Behavior (Assumptions and Instrument) \\ Marek Smulczyk (Poland) \\ The Maria Grzegorzewska Academy of Special Education}

The proposed approach to measuring interpersonal aggressive behavior is directed toward identification of specific psychological mechanisms of aggression. Based on the literature and analysis of existing instruments, it was established that interpersonal aggressive behaviors are consequences of activation: post-frustration emotions (emotogenic, reactive mechanism); task-oriented, normative beliefs (cognitive schemata and scripts mechanism); and immanent motivation towards aggression (immanent, proactive mechanism). Through appropriate psychometric procedure, the Inventory of Interpersonal Aggression was developed. The instrument consists of 30 items: for post-frustration, reactive pattern of aggression there are 10 items; to identify task-oriented, normative pattern of aggression there are 10 items; and there are 10 items for immanent, proactive motivation. It was established that: correlations between subscales are from 0.179 to 0.44 ; consistency of subscales is from 0.69 to 0.72 . Preliminary study shows that the patterns of interpersonal aggression behavior regulatory mechanisms are quite different among boys and girls and they differ among people characterized by various social roles. Individual subjects' scores of the Inventory of Interpersonal Aggression are presented in the form of a profile. 


\section{Death Anxiety Perceived by University Academics in Iraq}

Faris K. O. Nadhmi (Iraq/Sweden)

Baghdad University

According to local statistics, $80 \%$ of the assassinations of the Iraq Academics, targeted people working in the universities, and half of them are either professors or professor assistants, and majority of the victims were working in Baghdad University, Basra University, Mosul University or Al-Mostansiriya University. This study investigates the phenomenology of perceived death anxiety among university academics in major institutes in Iraq. A 15-item self-constructed Death Anxiety Inventory designed in accordance with the situation in Iraq was distributed to several faculties in the Baghdad University and Mostansiriya University. Results indicate that Iraqi scholars face extremely high level of death anxiety as mentioned below:

1. Afraid of painful death $(91 \%)$

2. Thinking of death of loved ones $(81 \%)$

3. Afraid of body deterioration that accompany slow death (72\%)

4. Worried about dying very painfully $(69 \%)$

5. Feeling that death is every where $(66 \%)$

6. Terrified of seeing a dead body $(66 \%)$

7. Obsession of getting killed any minute $(66 \%)$

8. Thinking of my personal death $(53 \%)$

9. Prefer not to attend a dying friend (53)

10. Would avoid death no matter whatever it takes $(50 \%)$

11. Think of death directly before going to bed (47\%)

12. Death is better than a painful life $(38 \%)$

13. Feel closer to death than to life (31\%)

14. Extremely afraid to die (31\%)

15. Terrified by the idea of decomposition after death $(28 \%)$

Cultural-values shared by Iraqi academics in coping with death anxiety are discussed. 
Right-wing terrorism in the United States with reference to Oklahoma City bombing on 19th April 1995 (Timothy McVeigh psychological and sociological case study)

Marcin Kazimierz Grega (Poland)

Jagiellonian University

The objective of this thesis is to present the problem of political rightwing extremism and terrorism in the United States. The theoretical part discusses basic definitions and examples and the typology related to the subject matter, such as rightist and religious inspired extremism/terrorism, as well as the most important circumstances and sources concerning the questions (political, ideological, sociological and psychological).

The second part is dedicated to the about 300 quasi terrorist organizations embracing several hundred thousand people in the USA. The following types of organizations are on the list of public enemies threatening home security: opponents of abortion, militant white racists, opponents to the federal government and simultaneously supporters of unlimited freedom, members of illegal militia organizations.

A substantial part is dedicated to and treats the Oklahoma City bombing of 19th April 1995, which the author regards as the climax of U.S. domestic terrorism in the 20th century. Not only the record of those events will be discussed but also the process of arising the ideology of hatred in defiance of U.S. authority, and the terrorists' psychological portrait, including their connections with and inspirations by the Militia Movement. 
Authoritarian orientations, threat of terrorism and preference for counter-terrorism strategies: Cross-culture comparisons

Matgorzata Kossowska \& Mariusz Trejtowicz (Poland)

Jagiellonian University

Alain Van Hiel (Belgium)

University of Gent

Soledad de Lemus (Spain)

Granada University

Robin Goodwin (United Kingdom)

Brunel University

The authors examined relationships among authoritarian orientations, perceived threat of terrorism, and preference for counter-terrorism strategies in countries experienced with terrorist attacks (e.g. United Kingdom, Spain) as well as those that have not suffered from terrorism yet (e.g. Poland, Belgium). Many studies show that although trauma and feelings of threat after 9/11 are independent of individual levels of authoritarian orientations (i.e. RWA and SDO), these variables affect attitudes towards terrorists and support for different strategies of fighting against terrorism (e.g. military actions, restrictions on human rights). The results of our studies in part supported these findings. They have shown that authoritarianism (but not SDO) is a good predictor of support for military actions against terrorists, irrespective of the threat level, but only in countries that have been victimised by acts of terror (i.e. United Kingdom, Spain). However, in countries that were not directly affected by terrorism (i.e. Poland, Belgium) perceived threat mediated the relationship between RWA and support for war on terror and employing military force. Thus, in these societies RWA is likely to be related to beliefs and assumptions about terrorism and terrorists that precede the militant attitudes. 


\section{- Session C: INTERNATIONAL SECURITY}

\section{Weak States and Terrorism}

Peter Tikuisis (Canada)

Defense Research \& Development Canada

The recent literature and public debate on failed and failing states has gained considerable attention owing to the purported association between weak states and the presence of terrorism. The majority-held view that weak states are more prone to harbour terrorist organizations than stronger states has recently been challenged and indeed a statistical analysis of the recent record conducted herein supports this contrary view. However, a strong relationship exists between weak states and domestic terrorism when the incidence of fatal attacks is compared between weak and stronger states. Weak states are at least 3 times more likely to experience fatal terrorist attacks than all other states. The implication of this finding is that weak states should be strengthened, even if certain of these states are presently not havens for terrorist groups, from a humanitarian perspective at a minimum and from a long-term strategic perspective in concurrence with various foreign policy statements. 


\section{Negotiating Hostage Crises with the New Terrorists}

Adam Dolnik (Australia)

University of Wollongong

The paper will build on a detailed analysis of recent case studies to outline the new trends in terrorist barricade hostage taking, and will highlight the adjustments that need to be made to the contemporary crisis negotiation protocols in order to improve the capacity of negotiators to deal with such incidents more effectively.

Al Qaida's hostage taking manuals as well as recent hostage crises such as the Moscow theater and the Beslan school are a clear indication that barricade hostage taking will henceforth entail a much greater willingness to execute hostages, will feature large teams of willing-to-die hostage takers who will have the capability to effectively repel a possible rescue operation, and who will also have detailed knowledge of the hostage negotiation and rescue teams' "playbook." If we are to keep up with the challenge, we must also learn from lessons of past attacks and adjust our response strategies accordingly. From the first glance, it is obvious that we are not prepared. While there are many trained crisis negotiators around the world, almost none of them have ever had contact with a terrorist hostage-taking incident. Further, the entire training program of most hostage negotiators focuses on resolving crises that do not take into consideration issues such as ideology, religion, or the differing set of objectives and mindsets of ideological hostage takers. This is especially true in regard to the terrorists of the "new" breed, who have become less discriminate, more lethal, and better prepared. Further, many of the paradigms and presumptions upon which the contemporary practice of hostage negotiation is based, simply do not reflect the reality of Beslan-type incidents. 


\section{Societal Reactions to Terrorism in Bulgaria: Mass Media and Security Institutions Interaction}

Tolya Angelova Stoitsova (Bulgaria)

New Bulgarian University

How and when mass media will reflect a certain terrorist act is an issue of greater significance in working out a specific terror strategy in modern societies than conducting the terror attacks themselves. Even more - we could say terrorism had converted itself into "a tragic form of audiovisual show business." Terrorism dictates new rules of news rating on TV and on the Internet, trying in this way to manipulate audience.

Reflecting terrorist attacks, and giving publicity to terrorists' wants, is part of the role society attributes to contemporary mass media. On the other hand, exercising its public role, media "helps" terrorists to achieve their goals.

South-East Europe is a region where it is easy to recognize what we call trance boundary terrorism. This is added to the reasons for establishing the National Anti-Terrorist Centre in Bulgaria that will unify professionals' potential for scientists, military and police experts, journalists and civil workers. At the present moment in Bulgaria the positive role of media could be revealed in two directions: First, in the popularization of the specific preventive institutional work that has been done as, fortunately, there have been no international terror attacks directly committed against Bulgaria. And second, mass media could facilitate the balance in connection between anti-terror institutions and present in this way useful information to civil citizens. 
Counterterrorism: An analysis of the non-conventional threat Guillermo Velarde \& Natividad Carpintero Santamaria (Spain) Polytechnical University of Madrid

The terrorist practice born in the shadow of the new international order derived from War World II had its most dramatic origin in the anti-NATO front groups, together with nationalist-separatism vindications and the hard-line organizations emerged in the Middle East in the aftermath of the 1967 Arab-Israeli War (Six Day War), which turned the European countries into a stage of international conflict under a rather controlled terror.

Today, and according to polls, the international community feels more vulnerable than never to the threat of international terrorism. For this reason, a more effective and demanding counter-terrorist strategy is needed, especially in those contexts in which could be perceived a potential practice of non-conventional aggression. This paper analyses different counter-terrorist measures that could be applied in the scenario of a CRBN attack. In the case of nuclear terrorism, countermeasures to dirty bombs and crude atom bombs are assessed.

\section{Trends in Suicide Terrorism}

Albert Jongman (The Netherlands)

Strategic Analyst, Dutch Ministry of Defense

In the 21 st century there has been an exponential growth of suicide terrorism, especially in the main theaters of the global jihad, e.g. Iraq, Afghanistan/Pakistan and the Israeli-Palestinian conflict. In my presentation I will deal with the reasons for this growth. Besides presenting new statistical data from a variety of sources for a number of relevant countries, I will pay attention to the logic of suicide terrorism, the different attack methods, the justifications for and the framing of suicide missions by various terrorist organizations. In the last section of the presentation I will focus on the vulnerabilities of society and the military in particular for this specific terrorist tactic and will identify a number of crucial factors that can play a role in thwarting suicide terrorism. 


\section{- KEYNOTE ADDRESS}

\section{Terrorism and Interpersonal Aggression: Conceptual Considerations from Social, Developmental Psychology Perspectives Adam Fraczek (Poland)} Past President of International Society for Research on Aggression Rector of Maria Grzegorzewska Academy of Special Education

In the presentation the two main issues are discussed. First, it is argued that understanding interpersonal aggressive behavior as an intentional act of introducing harm - that is commonly used in social psychology - is well applicable and useful in identification and description of terrorist acts (behavior). The cognitively advanced categorization of aggressive behaviors is based not so much on forms of manifestations (physical, verbal, indirect, relational) but on a nature of underlying psychological processes and structures. These regulatory mechanisms are identified as: post-frustration emotions (emotogenic, reactive mechanism); task-oriented, normative beliefs (cognitive schemata and script mechanism), and immanent motivation (specific needs, proactive mechanisms). Second, the question arises, what kind of socialization experiences and how they determine development and stabilization of cognitive schemata and scripts that influence, under specific circumstances, readiness to realize acts of terror (interpersonal aggressive behavior). In the proposed model of developmental path of this mechanism such elements are considered as: socio-cultural and family background (i.e. approval for aggression); instrumental training in using violent behavior; implementation of specific beliefs, ideas, etc. 


\section{- Session D: AGGRESSION AND VIOLENCE}

\section{Usefulness of categorizing functional aggression}

J. Martin Ramirez \& Jose M. Andreu (Spain)

Universidad Complutense Madrid

Aggression, far from being an univocous term, is a dynamic and multifaceted phenomenon, with different concepts under the same term. There is no agreement, however, in the attempts to categorize its different types. This explains the many classifications of aggression found in the literature. Some authors use the form of expression of the aggressive act as a criterion of classification; others prefer to focus aggression on its motivation, function, purpose, or goal. Even if distinguishing different forms of aggressive acts might seem useless, the categorization of the diverse functions or goals of aggression is very useful not only because it facilitates its theoretical development, but also for forensic practice, as well as for preventive and therapeutic interventions, because of its emphasis on the propensities and personalities of each individual.

\section{Cognitive Justification of Reactive-Proactive Aggression among Adolescents}

Jose M. Andreu, Carolina Marín, Rocio Mateos, \& J. Martin Ramirez (Spain)

Universidad Complutense Madrid

While aggression is a complex construct, convergent evidence supports a dichotomy of reactive (impulsive) and (premeditated) proactive aggressive subtypes that are qualitatively different from one another in terms of psychological and neurobiological processes. Socio-cognitive approaches have emphasized the important role of normative beliefs in the maintaining of aggressive behavior. In the present study, ninety-seven adolescents completed two questionnaires: the "Reactive-Proactive Questionnaire", designed by Raine et al. (2006) for characterizing reactive vs. proactive aggression, and the 
CAMA, designed by Ramirez (1985) for cognitive justification for aggression. Justification of aggression was associated with both reactive and proactive aggression $(\mathrm{r}=0.60 / \mathrm{r}=0.54 ; \mathrm{p}<0.05)$. This result appears to be relevant to understanding individual differences and socio-cognitive origins of aggression.

\section{Normative beliefs about aggression, emotional responding to violence and proactive/reactive aggression in young adults Lucyna A. Kirwil (Poland) \\ Warsaw School of Social Psychology}

Proactive aggression is assumed to be a premeditated, controlled action. Reactive aggression is seen rather as an inefficiently controlled angry reaction. It was hypothesized that in adult age proactive aggression and reactive aggression are related to different emotional traits and different sets of normative beliefs about aggression and emotional responses to violence. It was expected that the differences might result from experience in observing violence.

The only difference between two kinds of aggression in young adults, who did not have experience in observing violence, was found in their emotional traits. In the sample of young adults, who had such experience, two kinds of aggression correlated with different emotional traits, different normative beliefs and different emotional responses to observed violence. A crucial role of observing violence and normative beliefs about appropriateness of violence for formation of proactive aggression is discussed. 


\section{Sexual Violence against the Iraqi Women: Anthropo- psychological Perspective}

Faris K. O. Nadhmi (Iraq/Sweden)

Baghdad University

Sexual violence is an oblique behavior that includes moral and material infringement of a woman's body without her agreement or desire. This raping is performed by a man or a number of men due to several aggressive motives: biological, psychological or political. Most oriental societies, among them the Iraqi society, have the traditional belief that the chastity of women mainly lies in her body, not in her mind or personality. On the other hand, an important part of a man's dignity is decided according to his wife's "chastity" as well as that of his daughter, mother, sister, or any of his feminine relatives. The paradox that happened, and still happens till now, is that the man who produced this value of the taboo action is contravening it himself by steering his sexual ability in an aggressive way towards women with whom he is forbidden to make sexual intercourse. As an extension of this point of view, it could be confirmed that four authorities have practiced their mastery over the Iraqi woman forcing her to be subject to different types of sexual violence (social and political). These authorities are:

1. The Ex-Political Authority (Baath Regime) $(1968-2003)$.

2. The authority of the coalition occupation power (USA Army) (2003 - till now).

3. The current Theocratic political authority, simultaneously with extremist and terrorist religious groups (2003 - till now).

4. The social masculine authority of the Iraqi society.

Furthermore, this paper has suggested a number of psychological and social dimensions that may interpret this increasing sexual violence against Iraqi women:

1. The weakness of the Super Ego.

2. The general social violence.

3. The identification with the models of sexual culture.

4. The rumors of fear.

5. Blaming the victim. 


\section{The mutilation of "womeness" and the right to be human}

\section{Tina Lindhard (South Africa/Spain)}

We live in a society where the logos - the mind and the intellect - are highly prized. There is nothing wrong with this - the intellect has let us achieve wonders in the exterior physical world. But there has been a price - in developing the mind to such a great degree, we have ignored the soft whisper of the heart. Women are seen to be closer to their hearts - traditionally they are the caretakers and so they are more loving and kinder. Their ability to empathize with others is greater, as is their intuition. But these are not greatly valued in today's world these aspects are rarely acknowledged. In Spain, scientists talk about la idea feliz (the happy idea) from which they construct scientific ideas and theories but they do not openly acknowledge it as coming from the soft whispers of the 'female heart.' The philosopher S. Arka says that just as there is a metaphysical mind associated with the physical brain, so we have a centre - the spiritual heart, which is metaphysical and associated with the physical heart - even though science has little to say about this centre as yet. The spiritual journey of today's society would thus, be about the journey from mind to heart to consciousness. From the masculine mind to the emotional female heart - and only then can we proceed to higher states of consciousness. So the very values that will lead us to higher states are those which have not only been ignored in our society, but also are often looked down upon, especially in men and by men. Largely we live in a society where the emotional heart has been ignored and suppressed or if it is allowed at all, it is only in the context of the home. Of course the 'emotional heart' is in all of us, and is not exclusive to women. Maybe women are still closer to it than most men but if we are really to progress and find our true identity, then we are going to have to recover this part. It is suggested here that only when the feeling heart regains its place in all we think and say and do and we recover and enhance our ability to empathize and feel for the other, can we honestly say that our 'right to be human' has been restored. 
- Round Table: EXPERIENCES WITH AGGRESSION, TERRORISM, AND HUMAN RIGHTS ISSUES

Diamond Mark Eferigho Iriri (Nigeria)

Association of International Relations Students

Lagos State University

Mamdouh Darwish Jabr (Palestinian Territory)

Palestinian Committee for Social and Psychological Health

Joseph Okpalaugo (The Gambia)

Organization for Empowering Gambia Families (OEGAM) Kelvin Mensah (Ghana)

In the study of aggression, terrorism, and human rights it is important to open our minds and our hearts to hear the stories from those who may have first hand experience. We invite our colleagues from the Middle East and Africa to share their experiences in this Round Table discussion. 


\section{- KEYNOTE ADDRESS}

\section{Countering Myths about Terrorism}

Gary LaFree (USA)

Director, National Center for the Study of Terrorism and Responses to Terrorism (START)

The central irony in the current state of research on terrorism is that because it is a method designed to provoke emotional over reaction, effective policy is especially dependent on hard data and objective analysis and yet terrorism research is an area that is sadly lacking in terms of both empirical data and objective analysis. Even though there has been a tremendous outpouring of printed output on terrorism in recent years, much of this information has been journalistic and anecdotal, emphasizing especially sensational aspects of the lives of known terrorist figures. As a result of the general lack of research attention, an area that is especially in need of clear-eyed, dispassionate facts is especially susceptible to half truths and myths. For the past several years, the START Center at the University of Maryland has been collecting the world's most extensive open source data base on terrorism. The Global Terrorism Database (GTD) now includes more than 80,000 attacks from around the world starting in 1970. In my presentation I will use the GTD to examine trends in terrorist attacks and the geographical distribution of terrorism for the past 35 years. I will also provide data on the characteristics of global terrorism, including the types of weapons used, the number of fatalities, and the longevity of terrorist groups. My presentation will include a discussion of several case studies being undertaken by the START Center that examine how counter terrorist strategies by governments and strategic decisions made by terrorist organizations affected subsequent attacks. 
- Session E: PSYCHOLOGICAL

DETERMINANTS AND CONSEQUENCES OF TERRORISM THREAT

Nationalism, essentialism and perception of terrorist threat

Maciej Sekerdej (Portugal)

Centro de Investigaçao e Intervençao Social

Matgorzata Kossowska (Poland)

Jagiellonian University

This paper addresses the possible impact ones ingroup has on the perception of terrorism threat and support for particular methods of protection or/and prevention. Bearing in mind that terrorism constitutes an international, political problem, the group perception is also considered from the viewpoint of international politics, that is, from a national perspective. Combining sociological and psychological perspectives, the paper suggests that strong nationalist attitudes echo conceptions related to essentialism and entitativity, and civic attitudes promote a goal-oriented approach to a terrorist threat. Therefore, it is argued that if the individual subscribes to the nationalist/essentialist standpoint on one's own national group and international relations, it seems reasonable that in the face of a terrorism threat, $\mathrm{s}$ /he supports exclusionist policy, sealing the borders and military actions of defensive, preventive or even retaliatory character. By contrast, a civil/goal-driven approach would lead to negotiations, inclusion, individualization of the threat, and opposition against global solutions. 


\section{Threat of terrorism and support for antiterrorism policies}

Malgorzata Kossowska \& Anna Czerniak (Poland)

Jagiellonian University

Agnieszka Golec de Zavala (United Kingdom)

Middlesex University

The aim of the two consecutive studies is to determine reactions on terrorism threat and anxiety that shape support for government policies designed to combat terrorism. Based on the previous empirical findings we draw, a critical distinction between threat and anxiety rests on their typical psychological effects: anxiety leads to an overestimation of risk and risk-averse behaviour whereas external and perceived threat increases support for outwardly focused retaliation action. The differing psychological effects of anxiety and threat shed light on reactions to government antiterrorism policies. Perceived threat is likely to increase the desire for government retaliation against the enemy, whereas anxiety will undercut this support to the extent that the proposed retaliatory action is seen personally dangerous and risky. The role of political orientations (i.e. RWA and SDO) as well as cognitive representations of terrorism and terrorists are also examined in these studies. 


\section{Dehumanization and Moral Responsibility as Predictors of Outgroup-Focused Outcomes and Support for Terror Threat Prevention}

Anja Zimmermann (United Kingdom)

University of Cardiff/Amsterdam

Bertjan Doosje \& Sven Zebel (The Netherlands)

University of Amsterdam

Tendayi Viki \& Dominic Abrams (United Kingdom)

University of Kent

This research investigates the relationships of the four different dehumanization components (ingroup/outgroup humanity and ingroup/outgroup animality) with outcome variables related to terror threat prevention. We hypothesized a positive relationship between outgroup humanity and positive outgroup-focused outcomes (e.g. motivation to approach outgroup members and support for integration and negotiation of compromises with the Islamic world) and a negative relationship between outgroup animality and negative outcomes (e.g. prejudice and support for military intervention). Moral responsibility, as the adherence to moral principles and the motivation to change the status quo, is considered as mediator between outgroup humanity and the positive outcomes. A study conducted in the United Kingdom $(\mathrm{N}=170)$ assesses the different components of dehumanisation considering different outgroups who were victims of ingroup wrongdoing in the past (Kenyans) and in the present (Iraqis). The findings reveal the unique relationships in line with the hypotheses. The second study $(\mathrm{N}=160)$ manipulates different types of terrorist threat (realistic, symbolic, personal and no threat) and assesses implications of dehumanization on the different threat perceptions, intergroup anxiety, ingroup- and outgroup anger and support for different forms of terror threat prevention (mild, moderate, harsh). It is shown that outgroup animality is associated most strongly with symbolic threat, greater anxiety and support for harsher terrorist prevention. Implications of the findings for terror threat perception and prevention policies are considered and the distinct functions of outgroup humanity and outgroup animality for positive and negative outcomes are discussed. 


\section{Extremism + Threat $=$ Terrorism: Understanding terrorism from} a psycho-social perspective

Shahzad Shafqat (United Kingdom)

Cambridge University

This research was contrived by hypothesizing a theoretical premise for three concepts: 'threat' as an overt representation of a hostile emotion; 'extremism' as a polarization from the norm; and 'terrorism' as the hostile representation of this polarization. Two studies were carried out to measure how people perceive others as 'extremists'. By viewing the video of a person who was describing a religious induction, the sample was asked to form an opinion about the person. Before the video, there were four different stories about the background of the religious group, while a fifth control group had no background story. Each participant was introduced to only one version of the stories. The manipulations in the stories revolved around the incidence of extremism and threat. The findings of the studies provide credible psychological impetus for understanding the relationship between extremism, threat and terrorism, and how psycho-socially people identify with this issue. 


\section{LIST OF PARTICIPANTS}

(in alphabetical order)

\section{Prof. Abdolhossein Abdollahi}

Assistant Professor of Psychology

Islamic Azad University-Zarand Branch

Branch Kerman Shahid Bahonar University

PO Box 76185-1164

Kerman, Kerman 7618834589

IRAN

Cell:

0098-913-1424783

E-mail:

a_abdollahi@yahoo.com

Website:

http://abdollahi.socialpsychology.org/

\section{Dominic Abrams}

University of Kent

UNITED KINGDOM 


\section{Prof. Yonah Alexander}

Senior Fellow, Potomac Institute for Policy Studies

Senior Fellow, Homeland Security Policy Institute (George Washington University)

Director, Inter-University Center for Terrorism Studies

International Institute of Strategic Studies (London)

Authored over 95 books on international affairs and counterterrorism issues

35 years of service as a Professor and academic in counterterrorism studies

901 N. Stuart St., Suite 200

Arlington, VA 22203

USA

Phone: $\quad 0013012997778$

Cell: $\quad 0013015182823$

Fax: $\quad 0013012992142$

E-mail: $\quad$ yalexander@PotomacInstitute.org yonrazalex@hotmail.com

\section{Dr. Jose Manuel Andreu}

Member, Complutense Research Group on Aggression Academic Secretary, Clinical Psychology Department Specialty - Violence, Abnormal Psychology

Department of Personality, Assessment and Psychological Treatment School of Psychology

Complutense University of Madrid.

Campus of Somosaguas

SPAIN

Phone: 34913943122

Fax: 34913943189

E-mail: $\quad$ jmandreu@psi.ucm.es jmandreur@yahoo.com 
Kimberly Bistis, Psy.D.

Board Member at Large - Society for Terrorism Research

Psychologist

Department of Mental Health - Commonwealth of Massachusetts 165 Quincy Street

Brockton, MA 02302

USA

Phone: $\quad$ (617) 571-6688

Fax: (508) 897-2024

E-mail: $\quad$ Kimberly.Bistis@state.ma.us

kbistis@gmail.com

\section{Anita Blagojevic}

J. J. Strossmayer University of Osijek

Faculty of Law in Osijek

S. Radica 13

HR - 31000 Osijek

CROATIA

Phone: $\quad+38531224500$

Cell: $\quad$ +385981782710

E-mail: ablagoje@pravos.hr 
Natividad Carpintero-Santamaría, Ph.D.

Professor, Polytechnical University of Madrid

Diploma on National Defense

Corresponding Member of the European Academy of Sciences

Secretary General, Institute of Nuclear Fusion - UPM -

Polytechnic University of Madrid

José Gutiérrez Abascal n 2

28006 Madrid

SPAIN

Phone: $\quad+34913363108$

$+913363109$

E-mail: $\quad$ ncsantamaria@telefonica.net

\section{Micha Chmiel}

Ph.D. Student

Institute of Psychology

Jagiellonian University

POLAND

E-mail: $\quad$ michal.chmiel@apple.phils.uj.edu.pl

\section{Anna Czerniak}

Ph.D. Student

Institute of Psychology

Jagiellonian University

POLAND

E-mail: $\quad$ jabonobo@poczta.onet.pl 
Soledad de Lemus, Ph.D.

Grenada University

SPAIN

E-mail: $\quad$ slemus@ugr.es

\section{Dr. Adam Dolnik}

Director of Research Programs

Senior Research Fellow

Centre for Transnational Crime Prevention (CTCP)

University of Wollongong

NSW 2522

\section{AUSTRALIA}

Phone: $\quad+61242213255$

Mobile: $\quad+61408277942$

Fax: $\quad+61242213425$

E-mail: $\quad$ adamd@uow.edu.au

\section{Bertjan Doosje}

Department of Psychology

University of Amsterdam

Roeterstraat 15

Amsterdam 1018WB

THE NETHERLANDS 


\section{Jordi Escartín}

$\mathrm{Ph}$. D. Candidate

University of Barcelona

Departamento de Psicología Social

Universidad de Barcelona

Passeig de la Vall d'Hebron, 171

08035 - Barcelona

SPAIN

Phone: $\quad 933125197$

E-mail:_ jordiescartin@ub.edu

\section{Shira Fishman}

Doctoral Student

University of Maryland, College Park

1147 Biology/Psychology Building

University of Maryland

College Park, MD 20742

USA

Phone: $\quad 1$ (310) 314-9566

E-mail: sfishman@psyc.umd.edu 


\section{Prof. dr hab. Adam Fraczek}

Past President, International Society for Research on Aggression

Member of Academy Europaea

Head, Socialization and Aggression Research Group

Institute of Applied Psychology

Rector of the Maria Grzegorzewska Academy of Special Education

Szczęśliwicka 40

Warsaw 02-353

POLAND

Phone: $\quad$ +48606131324

E-mail: $\quad$ adamfra@poczta.onet.pl

\section{Iciar Galicia, MD}

Endocrinologist

Aggression Research Group

Universidad Complutense Madrid

SPAIN

Cell:

34616123283

E-mail: $\quad$ iciargalicia@hotmail.com

\section{Agnieszka M. Golec de Zavala, Ph.D.}

Middlesex University

Queensway

Enfield

Middlesex EN3 4SA

United Kingdom

Phone:

44 (0) 2084114902

E-mail:

agnieszka.golec@gmail.com 


\section{Robin Goodwin}

School of Social Sciences

Brunel University

Uxbridge London, UB8 3PH

United Kingdom

Phone: $\quad+441895265470$

E-mail: $\quad$ Robin.Goodwin@brunel.ac.uk

\section{Marcin Kazimierz Grega}

Ph.D. Candidate

Department of American Studies

Jagiellonian University

Master's Studies

Department of Cultural Studies: Middle and Far East Studies.

Major - Middle East Studies

2/7 Mazowiecka St.

Malopolska, Crakow 31-059

POLAND

Phone:

0-888-518-266

E-mail:

mkgrega@gmail.com 


\section{Diamond Mark Eferigho Iriri}

Student, Major of History and International Relations

Secretary, Association of International Relations Students - Festac Lagos State University

511 Road A Close Houase 12

P.O. Box 1970

Festac Town Lagos +234

NIGERIA

Phone: $\quad$ +2348035903630

E-mail: $\quad$ righocream@yahoo.co.uk

\section{Mamdouh Darwish Jabr, Ph.D.}

President of the Palestinian Committee for Social and Psychological Health

Professor in the development of family and social psychology

Arab League States Street

Tal El Hawa

Gaza Strip, Gaza

Palestinian Territory, 00972

Phone: $\quad 00972599745439$

Fax: $\quad 0097282821904$

E-mail: dr.mamdouh_jabr@hotmail.com 
Federico Javaloy, Ph.D.

Full Professor

University of Barcelona

Departamento de Psicología Social

Universidad de Barcelona

Passeig de la Vall d'Hebron, 171.

08035 - Barcelona

SPAIN

Phone: $\quad 933125179$

E-mail:_fjavaloy@ub.edu

\section{Albert Jongman}

Strategic Analyst

Dutch Ministry of Defense

Irislaan 253

Oegstgeest $2343 \mathrm{CL}$

THE NETHERLANDS

Phone: $\quad 31704419330$

E-mail: berto.jongman@gmail.com 


\section{Arthur J. Kendall, Ph.D.}

President, Social Research Consultants

Retired Sr. Mathematical Statistician, US Government Accountability Office

President, Capital Area Social Psychological Association (Washington, DC)

Member, AAAS Science and Human Rights Coalition

Editorial Board, Terrorism Research

Editorial Board, Peace and Conflict

Associate Editor, Dynamics of Asymmetric Conflict

6703 Forest Hill Drive

University Park, MD 20782-1438

USA

Phone: $\quad 1$ (301) $864-5570$

Fax: $\quad 1$ (301) 864-5570

E-mail: $\quad$ Art@DrKendall.org

\section{Lucyna A. Kirwil, Ph.D.}

Officer, International Society for Research on Aggression

Assistant Professor

Department of Social Psychology

Warsaw School of Social Psychology

19/31 Chodakowska Street

Warsaw 03-815

POLAND

$\begin{array}{ll}\text { Phone: } & +48501314506 \\ \text { Fax: } & +48227248085 \\ \text { E-mail: } & \text { lkirwil@swps.edu.pl }\end{array}$


Małgorzata Kossowska, Ph.D.

President of Polish Association of Social Psychology

Assistant Professor

Institute of Psychology

Jagiellonian University

Al. Mickiewicza 3

Krakow, 31-120

POLAND

Phone: $\quad+48126341305$

Fax: $\quad+48126237699$

E-mail: $\quad$ malgosia@apple.phils.uj.edu.pl

\section{Arie W. Kruglanski}

Distinguished University Professor

University of Maryland, College Park

1147 Biology/Psychology Building

University of Maryland

College Park, MD 20742

USA

Phone: (301) 405-5918

E-mail: $\quad$ arie@psyc.umd.edu 


\section{Tomasz Edward Kubik}

Ph.D. student

Institute of Psychology

Jagiellonian University of Cracow

Al. Mickiewicza 3

Cracow 31-120

POLAND

Phone: $\quad+48606222139$

E-mail: $\quad$ tom.kubik@gmail.com

\section{Gary LaFree, Ph.D.}

Director, START

National Center for the Study of Terrorism and Responses to

Terrorism

University of Maryland

3300 Symons Hall

College Park, MD 20742

USA

Phone: (301) 405-6600

Fax: $\quad$ (301) 314-1980

E-mail: $\quad$ glafree@msn.com

Web Site: http://www.start.umd.edu 


\section{Tina Lindhard}

Degree in Psychology

University of Cape Town

South Africa

Craneo-sacral Therapist

Meditation teacher

Pico de la Pala, 6

28792 Miraflores de la Sierra (Madrid)

SPAIN

Phone: $\quad 34659067797$

E-mail: $\quad$ terapias.de.tina@gmail.com

Website: http://www.tinalindhard.com

\section{Alice LoCicero, Ph.D., ABPP, MBA}

Former President, Society for Terrorism Research

Chair, Social Science

Endicott College

Beverly, MA 01915

USA

Phone: (978) 232-2156

E-mail: $\quad$ alice.locicero@gmail.com

Carolina Marin, Ph.D.

"Doctor Europaea" (Oxford-Complutense)

Aggression Research Group

Lecturer in Clinical Psychology

Universidad Complutense Madrid

SPAIN

Phone: $\quad 34699716428$

E-mail:_ carolmarin3@hotmail.com 


\section{Javier Martín Peña}

Doctoral Student

Departament de Psicologia Social

Facultat de Psicologia

Universitat de Barcelona

Passeig de la Vall d'Hebron, 171

08035 Barcelona

SPAIN

E-mail: $\quad$ javier_martin@ub.edu

\section{Dr. Rocio Mateos}

Aggression Research Group

Facultad de Psicología

Campus de Somosaguas

Universidad Complutense Madrid 28223 Pozuelo

SPAIN

E-mail: $\quad$ rmateos@psi.ucm.es

\section{Kendall McKay}

Student

Copy Editor, Society for Terrorism Research - Terrorism Research Case Western Reserve University

Cleveland, $\mathrm{OH}$

USA

Phone: $\quad 1$ (585) $750-5628$

E-mail: ｋkm16@case.edu 


\section{Kelvin Mensah}

\section{GHANA}

\section{Sam Mullins}

Centre for Transnational Crime Prevention

University of Wollongong

NSW 2522

\section{AUSTRALIA}

Phone: $\quad+61(0) 413547387$

E-mail: mullins103@hotmail.com

\section{Faris K. O. Nadhmi}

Doctoral Student

Baghdad University

Psychology Department

Instructor of Personality Psychology

Founding Member, Iraqi Psychological Association, IPA

Postgraduate member, European Association of Experimental Social Psychology (EAESP)

Fristadsgatan 10 B, 2 TR

63345 Eskilstuna

Sweden

E-mail: $\quad$ fariskonadhmi@hotmail.com 


\section{Joseph Okpalaugo}

Project and Social Communication Director

Organization for Empowering Gambia Families (OEGAM) Kotu East, Serekunda

K.M.C.D.

P.O Box 2232 Serekunda THE GAMBIA

\begin{tabular}{|c|}
\hline Phone: \\
\hline Fax: \\
\hline E-mail: \\
\hline Website: \\
\hline
\end{tabular}

\section{Edward Orehek}

Doctoral Student

University of Maryland, College Park

1147 Biology/Psychology Building

University of Maryland

College Park, MD 20742

USA

E-mail: $\quad$ eorehek@psyc.umd.edu 


\section{Dr. Elena Peña}

Aggression Research Group,

Department of Clinical Psychology

Facultad de Psicología

Campus de Somosaguas

Universidad Complutense Madrid

\section{Pozuelo}

SPAIN

Phone: $\quad 34913943128$

E-mail: $\quad$ elenapf@psi.ucm.es

\section{Clara Porrúa}

Ph.D. Candidate

University of Barcelona

Departamento de Psicología Social

Universidad de Barcelona

Passeig de la Vall d'Hebron, 171.

08035 - Barcelona

SPAIN

Phone: $\quad 933125177$

E-mail:_claraporrua@ub.edu 
J. Martin Ramirez, MD, $\mathrm{PhD}$, JD

Chairman of CICA

President, Spanish Pugwash Movement

Former Officer, ISRA

Diploma on National Defense

Former International Security Fellow, Harvard University

Editorial Board, International Journal on World Peace, Terrorism Research, and The Open Journal of Criminology

Professor of Psychobiology

Head, Aggression Research Group,

Universidad Complutense Madrid

Pico de la Pala, 6

28792 Miraflores (Madrid)

SPAIN

Phone: $\quad 34918444695$

Fax: $\quad 34913943069$

E-mail: $\quad$ mramirez@med.ucm.es

\section{Blanka Rip}

Doctoral Student

Université du Québec à Montréal

University of Maryland, College Park

1147 Biology/Psychology Building

University of Maryland

College Park, MD 20742

USA/CANADA
Phone:
(301) 405-8374
E-mail:
blanka.rip@gmail.com 


\section{Álvaro Rodríguez-Carballeira, Ph.D.}

Departamento de Psicología Social

University of Barcelona

Passeig de la Vall d'Hebron, 171

08035 - Barcelona

SPAIN

Phone: $\quad 933125178$

E-mail: alvaro.rodriguez@ub.edu

\section{Vivian Salama}

Journalist/Analyst

Formerly - Graduate School of Arts \& Sciences

Columbia University

UNITED ARAB EMIRATES

UAE cell: $\quad$ +971505964900

E-mail:_vmsalama@gmail.com

\section{Angela Scholes}

Ph.D. student c/o Psychology Department

University of Surrey

Guildford, Surrey GU2 7XH

ENGLAND
Phone:
01483686899
E-mail:
a.scholes@surrey.ac.uk 
Maciej Sekerdej, Ph.D.

Department of Social and Organizational Psychology

CIS-ISCTE

Lisbon, Portugal

Av. Forças Armadas Edificio (ISCTE)

1649 - 026 Lisboa

PORTUGAL

Phone: $\quad+351962367457$

E-mail: $\quad$ maciej.sekerdej@iscte.pt

\section{Shahzad Shafqat}

Department of Social and Developmental Psychology,

University of Cambridge

Downing College

Cambridge, CB2 1DQ

UNITED KINGDOM

Phone: $\quad+447516902611$

E-mail: $\quad$ ss797@cam.ac.uk

\section{Amanda M. Sharp Parker}

Doctoral Student

University of South Florida

306 SE $28^{\text {th }}$ Terrace

Cape Coral, FL 33904

USA

Phone: $\quad 1$ (252) 347-4818

E-mail: amsharp@mail.usf.edu 


\section{Marek Smulczyk}

Doctoral Student, Assistant

Socialization and Aggression Research Group

Institute of Applied Psychology

The Maria Grzegorzewska Academy of Special Education

Szczesliwicka 40

Woj. Mazowieckie

Warsaw 02-353

POLAND

Phone: $\quad 0048502215642$

E-Mail: $\quad$ smulczyk@tlen.pl

Tolya Angelova Stoitsova, Ph.D., D.Sc.

Professor

New Bulgarian University

Head of the Department of Mass Communication

21 Montevideo Street

Sofia 1618

BULGARIA

Work Phone: $\quad+28110408$

Cell: $\quad+878489326$

E-mail: $\quad$ tolya.stoitsova@gmail.com

tstoitsova@nbu.bg 


\section{Steven John Thompson}

Clemson University

Rhetorics, Communication, and Information Design Ph.D. Program

206A Strode Tower

Clemson SC 29634

USA

Phone: (619) 829-0552

(864) 656-2655

Email: $\quad$ stevent@clemson.edu

\section{Peter Tikuisis, Ph.D.}

Senior Scientist

Adversarial Intent Section

Defense Research \& Development Canada

1133 Sheppard Avenue West

Toronto, Ontario, M3M 3B9

CANADA

Phone: $\quad$ (001) 416-635-2099

Fax: $\quad$ (001) 416-635-2184

Email: $\quad$ Peter.Tikuisis@drdc-rddc.gc.ca

\section{Mariusz Trejtowicz}

Ph.D. Student

Institute of Psychology

Jagiellonian University

POLAND

E-mail: $\quad$ trejtowicz@onet.eu 


\section{Alain Van Hiel, Ph.D.}

Ghent University

BELGIUM

E-mail:_Alain.VanHiel@UGent.be

Guillermo Velarde, Ph.D.

General of Division of the Spanish Air Force

President of the Institute of Nuclear Fusion

Academician of the European Academy of Sciences

Chair Professor, Nuclear Physics

Institute of Nuclear Fusion - UPM

Polytechnical University of Madrid

C/ José Gutiérrez Abascal n ${ }^{\circ} 2$

28006 Madrid

SPAIN

Phone: $\quad+34913363108$

+ 913363109

E-mail: gvelarde@denim.upm.es

\section{Tendayi Viki}

University of Kent

UNITED KINGDOM 
Tali K. Walters, Ph.D.

Board Vice-President/Director of Conference Planning, Society for Terrorism Research

Assistant Professor of Psychiatry, Tufts University School of Medicine - Tufts Medical Center

Associate Editor, Terrorism Research

PO Box 8483

Boston, MA 02114

USA

Phone: $\quad 1(617) 899-5825$

Fax: $\quad 1$ (716) 288-5825

E-mail: $\quad$ tkwstr@gmail.com

Website: SocietyforTerrorismResearch.org

\section{Dr. Kinga Agnes Williams}

Clinical Psychologist, Cognitive Behavioural Psychotherapisy

Lecturer in Abnormal Psychology

MENSANA Intercultural Psychological Consultancy

29 Lockstile Way

Oxfordshire

Goring-on-Thames

RG8 0AL England

UNITED KINGDOM

Phone: $\quad$ 44(0)1491 872072

E-mail: mensana@mail.com 


\section{Dr. Margaret Wilson}

Psychology Department

University of Surrey

Guildford, Surrey GU2 7XH

ENGLAND

Phone: 44-1483-689439

E-mail: m.wilson@surrey.ac.uk

\section{Sven Zebel}

Department of Psychology

University of Amsterdam

Roeterstraat 15

Amsterdam 1018WB

THE NETHERLANDS

\section{Dr. Anja Zimmermann}

Department of Psychology

University of Amsterdam

Roeterstraat 15

Amsterdam 1018WB

THE NETHERLANDS

$\&$

University of Cardiff

Tower Building, Park Place

Cardiff,

WALES CF10 3AT

UK

Phone: $\quad$ +44 29-2087 0139

Fax: $\quad$ +44 29-20874858

E-mail: $\quad$ a.e.m.zimmermann@uva.nl 


\section{AUTHORS' INDEX}

(in alphabetical order)

Abdollahi $20,33,60$

Abrams $27,58,60$

Alexander $22,23,39,61$

Andreu $23,25,40,50,61$

Bistis 62

Blagojevic $21,35,62$

Carpintero-Santamaria $24,48,63$

Chmiel 63

Czerniak $27,57,63$

de Lemus $23,44,64$

Dolnik $24,46,64$

Doosje $27,58,64$

Escartín $20,31,65$

Fishman $20,29,65$

Fraczek $24,25,49,66$

Galicia $23,40,66$

Golec de Zavala $27,57,66$

Goodwin $23,44,67$

Grega $23,43,67$

Iriri $25,54,68$

Jabr $25,54,68$

Javaloy $20,31,69$

Jongman $24,48,69$

Kendall $21,34,70$

Kirwil $25,51,70$

Kossowska $20,23,27,30,44,56,57,71$

Kruglanski $20,29,71$

Kubik $20,30,72$

LaFree $27,55,72$

Lindhard $25,53,75$ 
LoCicero $20,26,30,73$

Marin $24,25,40,50,73$

Martín-Peña $23,40,74$

Mateos $24,25,40,50,74$

McKay 74

Mensah $25,54,75$

Mullins $21,36,75$

Nadhmi $23,25,42,52,75$

Okpalaugo $25,54,76$

Orehek $20,29,76$

Peña $20,23,31,40,77$

Porrúa $20,31,77$

Ramirez $19,23,24,25,40,50,78$

Rip $20,29,78$

Rodríguez-Carballeira $20,31,79$

Salama $22,38,79$

Scholes $22,36,79$

Sekerdej $27,56,80$

Shafqat $27,59,80$

Sharp Parker $21,35,80$

Smulczyk $23,41,81$

Stoitsova $24,47,81$

Thompson $22,37,82$

Tikuisis $23,45,82$

Trejtowicz $23,44,82$

Van Hiel $23,44,83$

Velarde $22,24,48,83$

Viki $27,59,83$

Walters $19,20,27,84$

Williams $20,32,84$

Wilson $22,36,85$

Zebel $27,58,85$

Zimmermann $27,58,85$ 
NOTES 
NOTES 
NOTES 
NOTES 
NOTES 
NOTES 
NOTES 
NOTES 